\title{
Factors Affecting Customer Loyalty in Products
}

\author{
Jefry Romdonny ${ }^{1}$, Maskarto Lucky Nara Rosmadi ${ }^{2 *}$ \\ ${ }^{I}$ Institute of Economic Science STMy, Majalengka, Indonesia \\ ${ }^{2}$ Institute of Economic Science Kridatama Bandung, Indonesia \\ maskartolucky@gmail.com
}

\begin{abstract}
This study aims to determine the factors that can influence consumers have loyalty to a product produced by a company. The research method used is a qualitative method with a descriptive analytical approach. From the results of research conducted, it is known that customer loyalty is needed by producers, especially to market their products as well as the commitment of management to provide satisfactory service and quality products needed by consumers. The role of the government is often needed especially to overcome the high price of production raw materials because it is still imported from abroad.
\end{abstract}

Keywords : customer loyalty; brand image; product quality

\section{Introduction}

In the world of marketing, consumers are assets that must be maintained and maintained their existence in order to remain consistent with the products we produce. One form of commitment that must be given to consumers is by providing good and satisfying services and leading to the creation of customer loyalty [1], [2]. In addition, product quality that meets consumer needs will also have an impact on increasing the brand image of a product that has high competitiveness that is much in demand by users of the product and it is a distinct advantage for producers [3]-[4]. With customer loyalty to the products produced by the company, it will make it easier for consumers to recommend products to other consumers [5]. Therefore customer loyalty is very important for the development of business organizations, especially in the banking sector [6], [7] the hotel and leisure sector [8] and the retail industry sector [9].

To get consumers who have loyalty to the products produced, of course, must be supported by marketing strategies and good product quality, especially those needed and can provide satisfaction to consumers [10] - [11]. With marketing strategies and product quality that has value and competitiveness. the high will win the competition and gain loyalty from customers [12] - [13]. This will also support the brand image of the products produced by the company and motivate customers to increase loyalty [14] - [15]. From the description above, the purpose of the research conducted by the author is to find out the factors that cause customers to have high loyalty to a product.

\section{Review of Literature}

\subsection{Customer Loyalty}

The development of business organizations can be realized if supported by two very significant factors, namely customer satisfaction and loyalty for the products we produce [16] - [17]. The greater the satisfaction received by consumers and the higher the value of customer loyalty, the greater the profits the company will get. However, customer satisfaction is also strongly influenced by the attitudes and behavior of consumers themselves [18] - [19]. From the results of research conducted by Fullerton \& Taylor [20], Caruana [21], Jahanshahi 
et al. [22], Dimyati [23], and Bei \& Chiao [10] it can be concluded that customer loyalty can be caused by several factors including good service quality, competitive prices, and satisfaction with product quality.

\subsection{Brand Image}

Brand image grows and develops along with the number of consumers who use products produced by business organizations. The choice of a product by consumers starts from the experience and knowledge of previous consumers in buying products. A good brand image is a positive manifestation for companies whose products can be accepted by consumers because they have characteristics and advantages compared to similar products from other companies [24] - [25]. This is supported by the opinion expressed by lau \& Phau [26], Rubio et al. [27], and Diallo et al. [28] which states that brand image is the trust given by consumers to a particular product. From the results of research conducted by Khan et al. [29], Chi et al. [27], and Rubio et al. [30] it can be concluded that the brand image of a production result has a positive impact on consumer loyalty.

\subsection{Product quality}

The development of business organizations depends on the quality of the products they produce. The better the product produced and useful, the more consumers will enjoy it, especially to meet their daily needs. The quality of products that are in great demand by consumers can be seen from several factors including packaging, price, quality, and benefits obtained by consumers [31] - [32].With good product quality it will have an impact on consumer loyalty and increase revenue for producers [33], [34]. This is confirmed by the opinion of Halim et al. [35] that products that have good quality will have an impact on increasing consumer loyalty. The results of research conducted by Chinomona et al. [32], agyekum et al. [31], and Halim et al. [36], Akbar [37], Bobalca [38], and Doney \& Cannon [39] it can be concluded that quality products have a very strong impact and have a positive effect on consumers to be loyal to the products produced by a company.

\section{Research Methods}

The research was conducted at PT. Sinjaraga Santika Sport located in Majalengka Regency. The company produces soccer balls both for domestic and foreign consumption. The method used is a qualitative method with a descriptive explorative approach. The type of data collected is primary data obtained through in-depth interviews with information sources (informants). In conducting surveys, researchers use a personal approach (unstructured questionnaire) to obtain information related to the bag industry business. Data analysis techniques in this study used a descriptive qualitative interactive model in the form of data collection, data reduction, display data, and conclusions / interpretative verification.

\section{Results and Discussion}

From the results of research conducted at PT. Sinjaraga Santika Sport (Triple S) related to consumer loyalty when compared to companies that produce similar products can be seen in the following table: 
Table 1. Comparison of Marketing Activities and Brand Licenses

\begin{tabular}{|l|c|c|c|}
\hline \multirow{2}{*}{\multicolumn{1}{|c|}{ Marketing Activities and Brand Licenses }} & \multicolumn{3}{c|}{ Brand } \\
\cline { 2 - 4 } & Triple S & Proteam & Pespex \\
\hline Ekpor & $\sqrt{ }$ & $\sqrt{ }$ & $\sqrt{ }$ \\
\hline Online & $\sqrt{ }$ & $\sqrt{ }$ & $\sqrt{ }$ \\
\hline Supermarket (such as Carefour, Hypermart, etc) & - & $\sqrt{ }$ & $\sqrt{ }$ \\
\hline Sekolah Sepak Bola & $\sqrt{ }$ & $\sqrt{ }$ & $\sqrt{ }$ \\
\hline Own Shop in the mall & - & - & - \\
\hline FIFA License & $\sqrt{ }$ & - & - \\
\hline
\end{tabular}

Source: Data processed from various sources

From table 1 above it can be explained that consumers become loyal to the products produced by PT. Sinjaraga Santika Sport (Triple S) because it has advantages that are not owned by similar companies such as those licensed by FIFA. In addition, the price offered varies from Rp. 60,000 up to Rp. 300,000 per unit. This price for domestic consumption is very competitive in competition, because almost all domestic soccer ball producers offer prices as listed above. Therefore, PT. Sinjaraga Santika Sport (Triple S) chooses foreign markets to market their products both online and conventional. This is done by more promising and prospective foreign markets for the development of the soccer industry and supported by optimal service to consumers. This is in line with the opinion expressed by Dimyati \& Subagyo [1] and Djumarno \& Djamaludin [2] that the existence of high commitment from producers in the form of satisfying service to consumers will have a positive impact on customer loyalty.

With the license obtained from FIFA for the quality of soccer balls produced by PT. Sinjaraga Santika Sport (Triple S) has an impact on brands and sales as shown in the following table:

Table 2. Data on Triple S Ball Sales for the 2016-2018 Period

\begin{tabular}{|c|c|}
\hline Year & $\begin{array}{c}\text { Value of Selling Triple S } \\
\text { soccer balls (Rp) }\end{array}$ \\
\hline 2016 & 1.371 .465 .000 \\
\hline 2017 & 2.193 .895 .494 \\
\hline 2018 & 3.587 .808 .000 \\
\hline
\end{tabular}

From table 2 it can be explained that the quality of products produced by PT. Sinjaraga Santika Sport (Triple S) can be accepted by overseas consumers. This is evident from the increase in the value of transactions generated has increased. This of course is inseparable from the license issued by FIFA and the company's commitment to provide the best service to achieve customer satisfaction. This certainly supports the opinion expressed by Anderson \& Sullivan [31], and Almaamari [32] that good and quality product quality and the amount of benefits consumers can get will have an impact on brand image which will ultimately create loyalty consumer.

However, various kinds of obstacles and obstacles were also felt by the management of PT. Sinjaraga Santika Sport (Triple S) is mainly related to the high price of raw materials due to the majority of which are still imported from abroad. Other problems faced are related to 
the quality of human resources and high bank interest rates. Therefore support from the government is needed for the continuity and development of PT. Sinjaraga Santika Sport (Triple S).

\section{Conclusion}

From the description above, it can be seen that customer loyalty can be formed from the commitment of the management of business organizations to provide the best for consumers, especially related to product quality, competitive prices, and satisfying services. However, several obstacles faced by business organizations include high raw materials, and capital. Therefore, the role of the government is highly expected by business actors, especially related to the import policy of raw materials which is considered very burdensome to producers.

\section{References}

[1] Mohamad Dimyati and N. Ari Subagio, "Impact of Service Quality, Price, and Brand on Loyalty with the mediation of Customer Satisfaction on Pos Ekspres in East Java," Mediterranean Journal of Social Sciences, vol. 7, no. 4, pp. 74-86, 2016.

[2] Santrianimatina Anjani Djumarno and Said Djamaluddin, "Effect of Product Quality and Price on Customer Loyalty through Customer Satisfaction," International Journal of Business and Management Invention (IJBMI), vol. 7, no. 8 Ver. I, pp. 12-20, August 2018.

[3] Mohsen Shafiei Nikabadi, Maedeh Dehghan, and Maraym Farmanian Arani, "The effect of knowledge management strategies on performance of new product development in knowledge-based companies," Indian Journal of Science and Technology, vol. 8, no. S7, pp. 263-277, April 2015.

[4] James L. Heskett, "Beyond Customer Loyalty," Managing Service Quality: An International Journal, vol. 12, no. 6, pp. 355-357, 2002.

[5] Daniel Onwonga Auka, J.N. Bosire, and V. Matern, "Perceived service quality and customer loyalty in retail banking in Kenya," British Journal of Marketing Studies, vol. 1, no. 3, pp. 32-61, January 2013.

[6] Mohamad Noorman Masrek, Normah Binti Omar, Nora'ayu Ahmad Uzir, and Irni Eliana Khairuddin, "Mobile Banking Utilizations, Satisfaction and Loyalty: A Case Study of Malaysian Consumers," Science Series Data Report, vol. 4, no. 12, pp. 20-29, December 2012.

[7] Naif Mutlaq Al Otaibi and Kausar Yasmeen, "An Overview of Customer loyalty, Perceived Service Quality and Customer Satisfaction: Brief on Saudi Grocery Stores," Journal of Entrepreneurship and Business Innovation, vol. 1, no. 1, pp. 79-122, March 2014.

[8] Mustafa I. Eid, "Determinants of e-commerce customer satisfaction, trust, and loyalty in Saudi Arabia," Journal of Electronic Connerce Research, vol. 12, no. 1, pp. 78-93, January 2011.

[9] Lien Ti Bei and Yu-Ching Chiao, "An Integrated Model for The Effects of Perceived Product, Perceived Service Quality, and Perceived Price Fairness on Consumer 
Satisfaction and Loyalty," Journal of Consumer Satisfaction, Dissatisfaction and Complaining Behavior, vol. 14, pp. 125-140, February 2001.

[10] Tinik Sugiarti, Armanu Thoyib, Djumilah Hadiwidjojo, and Margono Setiawan, "The Role of Customer Value on Satisfaction and Loyalty (Study on Hipermart's Customer)," International Journal of Business and Management Invention, vol. 2, no. 6, pp. 65-70, June 2013.

[11] Jochen Wirtz, "Halo in customer satisfaction measures: The role of purpose of rating, number of attributes and customer involvement," International Journal of Service Industry Management, vol. 14, no. 1, pp. 96-119, 2003.

[12] M. Fathollahzadeh, A. Hashemi, and Mohammad Safari, "Designing a new model for determining customer value satisfaction and loyalty towards banking sector of Iran," European Journal of Economics, Finance and Administrative Sciences, vol. 28, no. 1, pp. 126-138, January 2011.

[13] Manoj Edward, Babu George, and Sudipta Kiran Sarkar, "The impact of switching costs upon the service quality-perceived value-customer satisfaction-service loyalty chain: a study in the context of cellular services in India," Services Marketing Quarterly, vol. 31, no. 2, pp. 151-173, March 2010.

[14] Mamoun N. Akroush, Amjad Abu ELSamen, Motteh Saleh Al-Shibly, and Fayez M. AlKhawaldeh, "Conceptualisation and development of customer service skills scale: an investigation of Jordanian customers," International Journal of Mobile Communications, vol. 8, no. 6, pp. 625-653, January 2010.

[15] Gordon Fullerton and Shirley Taylor, "Mediating, Interactive, and Non Linear Effects in Service Quality and Satusfaction with Services Research," Canadian Journal of Administrative Science, vol. 19, no. 2, pp. 124-136, June 2002.

[16] Albert Caruana, "Service loyalty: The effects of service quality and the mediating role of customer satisfaction," European Journal of Marketing, vol. 36, no. 7/8, pp. 811-828, 2002.

[17] Farai Chigora and Promise Zvavahera, "Awareness completes brand loyalty: Reality of Zimbabwe Tourism Destination," Business and Management Horizons, vol. 3, no. 2, pp. 60-69, November 2015.

[18] Kong Cheen Lau and Ian Phau, "Extending symbolic brands using their personality: examining antecedents and implications towards brand image fit and brand dilution," Psychology and Marketing, vol. 24, no. 5, pp. 421-444, May 2007.

[19] Natalia Rubio, Javier Oubina, and Nieves Villasenor, "Brand awareness-Brand quality inference and consumer's risk perception in store brands of food products," Food and Preference, vol. 32, pp. 289-298, March 2014.

[20] Mbaye Fall Diallo, Jean-Louis Chandon, Gerard Cliquet, and Jean Philippe, "Factors influencing consumer behaviour towards store brands: evidence from the French market," International Journal of Retail \& Distribution Management, vol. 41, no. 6, pp. 422-441, June 2013.

[21] Afak Ahmed Khan, Saneela Jadoon, and Naqash Ahmad Khan Tareen, "Impact of Advertising on Brand Awareness and Commitment in Female Apparel Industry," International Journal of Academic Research in Business and Social Sciences, vol. 6, no. 
3, pp. 79-94, April 2016.

[22] H.K Chi, Huery Ren Yeh, and Y.T. Yang, "The Impact of Brand Awareness on Consumer Purchase Intention: The Mediating Effect of Perceived Quality and Brand Loyalty," The Journal of International Management Studies, vol. 4, no. 1, pp. 135-144, January 2009.

[23] Crentsil Kofi Agyekum, Huang Haifeng, and Amma Agyeiwaa, "Consumer Perception of Product Quality," Microeconomics and Macroeconomics, vol. 3, no. 2, pp. 25-29, July 2015.

[24] Mohammad Majid Mehmood Bagram and Shahzad Khan, "Attaining Customer Loyalty! The Role of Consumer Attitude and Consumer Behavior," International Review of Management and Business Research, vol. 1, no. 1, pp. 1-8, December 2012.

[25] Petr Suchanek, Jiri Richter, and Maria Kralova, "Customer Satisfaction, Product Quality and Performance of Companies," Review of Economic Perspectives, vol. 14, no. 4, pp. 329-344, January 2014.

[26] Peter Halim, Bambang Swasto, Djamhur Hamid, and M. Riza Firdaus, "The Influence of Product Quality, Brand Image, and Quality of Service to Customer Trust and Implication on Customer Loyalty (Survey on Customer Brand Sharp Electronics Product at the South Kalimantan Province)," European Journal of Business and Management, vol. 6, no. 29, pp. 159-166, 2014.

[27] John E. Hogan, Katherine N. Lemon, and Barak Libai, "What is the true value of a lost customer?," Journal of Service Research, vol. 5, no. 3, pp. 196-208, 2003.

[28] Laiq Muhammad Khan and Rizwan Ahmed, "A Comparative Study of Consumer Perception of Product Quality: Chinese versus Non-Chinese Products," Journal of PJETS, vol. 2, no. 2, pp. 118-143, June 2012.

[29] Yan Ma, Jianxun Ding, and Wenxia Hong, "Delivering Customer Value Based an Service Process: The Example of Tesco.com," International Business Research, vol. 3, no. 2, pp. 131-135, July 2010.

[30] Eugene W. Anderson and Mary W. Sullivan, "The antecedents and consequences of customer satisfaction for firms," Marketing Science, vol. 12, no. 2, pp. 125-143, 1993.

[31] Claes Fornell, "A national customer satisfaction barometer: The Swedish experience," The Journal of Marketing, vol. 56, no. 1, pp. 6-21, January 1992.

[32] Qais Almaamari, A. Hashemi, Bassam A. Aljamrh, and Abdo Hasan Al-Harasi, "The Relationship Between Total Quality Management Practices and Individual Readiness for Change at Petroleum Exploration and Production Authority in Yemen," International Journal of Business and Industrial Marketing, vol. 2, no. 6, pp. 48-55, January 2017.

[33] Mamoun N. Akroush, Samer M. Al-Mohammad, Majdy I. Zuriekat, and Bayan N. AbuLail, "An empirical model of customer loyalty in the Jordanian mobile telecommunications market," International Journal of Mobile Communications, vol. 9, no. 1, pp. 76-101, January 2011.

[34] Manilall Dhurup, Chengedzai Mafini, and Tshepiso Dumasi, "The impact of packaging, price and brand awareness on brand loyalty: Evidence from the paint retailing industry," Acta Commercii, vol. 14, no. 1, pp. 1-9, April 2014. 
[35] Ismail Razak, Nazief Nirwanto, and Boge Triatmanto, "The Impact of Product Quality and Price on Customer Satisfaction with the Mediator of Customer Value," Journal of Marketing and Consumer Research, vol. 30, pp. 59-68, 2016.

[36] Mohammad Akbar, "Three Competing Models on Customer Loyalty in the Context of Mobile Subscribers," International Journal of Marketing Studies, vol. 5, no. 4, pp. 42-58, 2013.

[37] Claudia Bobalca, "Determinants of Customer Loyalty. A Theoretical Approach," Economy \& Business Journal, vol. 8, no. 1, pp. 995-1005, 2014.

[38] Patricia M. Doney and Joseph P. Cannon, "An Examination of the Nature of Trust in Buyer-Seller Relationships," Journal of Marketing, vol. 61, no. 2, pp. 35-51, April 1997.

[39] Maskarto Lucky Nara Rosmadi, "Factors in Developing Creative Industry," Budapest International Research and Critics Institute-Journal (BIRCI-Journal), vol. 1, no. 4, pp. 64-69, December 2018. 